\title{
Shrews (Soricidae) of the lowland forests around Kisangani (DR Congo)
}

\author{
Frederik Van de Perre $\ddagger^{\ddagger}$, Herwig Leirs ${ }^{\ddagger}$, Julien Cigar§ , Sylvestre Gambalemoke Mbalitinil, Jean-Claude \\ Mukinzi Itoka", Erik Verheyen ${ }^{\#, \mp}$ \\ ‡ Evolutionary Ecology Group, University of Antwerp, Antwerp, Belgium \\ $\S$ Belgian Biodiversity Platform, Brussels, Belgium \\ | Centre de Surveillance de la Biodiversité, Kisangani, Democratic Republic of the Congo \\ I Faculté des Sciences, UNIKIS, Kisangani, Democratic Republic of the Congo \\ \# Royal Belgian Institute of Natural Sciences, Brussels, Belgium
}

Corresponding author: Frederik Van de Perre (frederik.vandeperre@uantwerpen.be)

Academic editor: Alexander E Balakirev

Received: 30 Sep 2019 |Accepted: 01 Nov 2019 | Published: 20 Dec 2019

Citation: Van de Perre F, Leirs H, Cigar J, Gambalemoke Mbalitini S, Mukinzi Itoka J-C, Verheyen E (2019)

Shrews (Soricidae) of the lowland forests around Kisangani (DR Congo). Biodiversity Data Journal 7: e46948.

https://doi.org/10.3897/BDJ.7.e46948

\begin{abstract}
Background

The Congo Basin rainforest is the second largest rainforest in the world and one of the most biodiverse regions on Earth. Nevertheless, the Congo Basin biodiversity remains to be fully mapped, with many species awaiting discovery or official description. In recent years, much effort has been put into research on shrews (Soricidae), particularly in the region around Kisangani (D.R. Congo). Shrews are opportunistic feeders that are able to forage on a large diversity of invertebrate prey and therefore play an important role in the forest ecosystem. Furthermore, as they largely depend on forest habitats and have limited dispersal capacities, shrews form an interesting model group to study biogeographic patterns in the Congo Basin.
\end{abstract}




\section{New information}

This paper collates the efforts on shrew research from the wider region around Kisangani, in the centre of the Congo Basin. Apart from sampling information, the dataset includes morphological measures, DNA sequences and photographs. This dataset is therefore critical in the study of the taxonomy and ecology of Soricidae in the Congo Basin lowland rainforests.

\section{Keywords}

pitfall, removal trapping, tropical lowland forest, Democratic Republic Congo, Soricidae

\section{Introduction}

The Congo basin rainforest is the second largest in the world and one of the most biodiverse regions on earth (Mittermeier et al. 2003, Lewis 2005). Both the forest and its biodiversity are threatened by forest loss and bushmeat hunting (Malhi et al. 2013). Despite its importance for climate change mitigation and biodiversity conservation, knowledge on the impact of forest loss and degradation and bushmeat hunting on local biodiversity is currently lacking (Gibson et al. 2011, Alroy 2017, Phillips et al. 2017). In fact, the biodiversity of the Congo basin is generally understudied, with several new species being discovered every year (e.g. Colyn et al. 2010, Stanley et al. 2013).

Our knowledge on occurrence, ecology and taxonomy of shrews (Soricidae) in the Congo basin is currently incomplete (Mukinzi et al. 2005, Gambalemoke 2014, Jacquet et al. 2015). Shrews represent critical food web links via their role as predators of small vertebrates and invertebrates and as prey for several vertebrate predators (Churchfield et al. 2004). Apart from their importance in the ecosystem, shrews are also a suitable model taxon for evaluating biogeographic and historical hypotheses (Quérouil et al. 2003). Indeed, the central Congo basin (i.e. the lowland forests south of the Congo river) harbours less terrestrial vertebrate species than the northern part which is due to the smaller habitat area and isolated position of the central Congolian lowland forests (Van de Perre et al. 2019). As richness is limited by habitat area and isolation, this implies that diversity differences amongst Congolian lowland forests are mostly due to forest-associated taxa with limited dispersal capacities, such as shrews.

Therefore, this paper assembles shrew occurrences from three studies in the central Congo Basin (Gambalemoke et al. 2008b, Mukinzi 2014, Van de Perre et al. 2018) and includes the metadata of the captured specimens (morphological measurements, DNA and sampling details) which allows for the advancement of the knowledge on taxonomy and ecology of shrews in the central Congo basin. 


\section{General description}

Purpose: This paper assembles data collected in the framework of the PhD theses of Jean-Claude Mukinzi Itoka, Sylvestre Gambalemoke Mbalitini and Frederik Van de Perre. These three theses were executed at or in collaboration with the University of Kisangani, the University of Antwerp and the Royal Belgian Institute for Natural Sciences. Although the design and purpose of the three studies differ, the sampling design (the method in which shrews were collected) is equal across studies, which justifies the publication of the dataset as a whole.

\section{Project description}

Study area description: We compiled data from three studies in the region around Kisangani (Gambalemoke et al. 2008b, Mukinzi 2014, Van de Perre et al. 2018). The combined data represent 36 sampling sites in which sampling effort was equal and distributed within 6 localities in the Tshopo Province (Fig. 1 and Table 1). Sampling localities are separated by the Congo River and some of its major tributaries (Tshopo, Lindi, Lomami).

\section{Table 1.}

List of sampling sites including locality (and initials of collectors), coordinates, forest type (OG-X: Mixed old-growth forest; OG-M: Monodominant old-growth forest; RF: Regrowth forest; FL: Fallow land; OP: abandoned oil palm plantation), number of trapping sessions, start date of trapping and range of field numbers under which specimens are stored.

\begin{tabular}{|c|c|c|c|c|c|c|c|}
\hline Locality & Latitude & Longitude & Site & $\begin{array}{l}\text { Forest } \\
\text { type }\end{array}$ & $\begin{array}{l}\text { Number of } \\
\text { trapping } \\
\text { sessions }\end{array}$ & Start date & Field numbers \\
\hline \multirow{3}{*}{$\begin{array}{l}\text { Baliko } \\
\text { (SG) }\end{array}$} & 0.6415 & 26.3639 & Baliko_FP & OG-X & 1 & 23/09/2006 & \multirow[t]{3}{*}{ BA77-675 } \\
\hline & 0.6415 & 26.3639 & Baliko_FS & RF & 1 & 23/09/2006 & \\
\hline & 0.6415 & 26.3639 & Baliko_JC & $\mathrm{FL}$ & 1 & 23/09/2006 & \\
\hline \multirow{3}{*}{$\begin{array}{l}\text { Djabir } \\
\text { (JCM, } \\
\text { SG) }\end{array}$} & 0.5192 & 24.1736 & Djabir_FP_L1 & OG-X & 1 & $13 / 10 / 2005$ & \multirow[t]{3}{*}{ DJ1-567 } \\
\hline & 0.5192 & 24.1736 & Djabir_FP_L2 & OG-X & 1 & $13 / 10 / 2005$ & \\
\hline & 0.5192 & 24.1736 & Djabir_FS & $\mathrm{RF}$ & 1 & $13 / 10 / 2005$ & \\
\hline \multirow{6}{*}{$\begin{array}{l}\text { Masako } \\
\text { (JCM, } \\
\text { SG) }\end{array}$} & 0.6051 & 25.2565 & Masako_FP & OG-X & 1 & $2 / 06 / 2005$ & \multirow[t]{2}{*}{ R27985-28242 } \\
\hline & 0.6051 & 25.2565 & Masako_FS & $\mathrm{RF}$ & 1 & $2 / 06 / 2005$ & \\
\hline & 0.6051 & 25.2565 & Masako_FS_L1A & RF & 1 & $12 / 03 / 2011$ & \multirow[t]{2}{*}{ CRT3151-3520 } \\
\hline & 0.6051 & 25.2565 & Masako_FS_L1C & $\mathrm{RF}$ & 1 & $12 / 03 / 2011$ & \\
\hline & 0.6051 & 25.2565 & Masako_Gil_L1A & OG-M & 1 & 27/03/2012 & \multirow[t]{2}{*}{ MSK1-362 } \\
\hline & 0.6051 & 25.2565 & Masako_Gil_L1C & OG-M & 1 & 27/03/2012 & \\
\hline
\end{tabular}




\begin{tabular}{|c|c|c|c|c|c|c|c|}
\hline Locality & Latitude & Longitude & Site & $\begin{array}{l}\text { Forest } \\
\text { type }\end{array}$ & $\begin{array}{l}\text { Number of } \\
\text { trapping } \\
\text { sessions }\end{array}$ & Start date & Field numbers \\
\hline \multirow{12}{*}{$\begin{array}{l}\text { Yangambi } \\
(\mathrm{FVdP})\end{array}$} & 0.8144 & 24.4937 & Yangambi_BRA1 & OG-M & 1 & $12 / 07 / 2015$ & \multirow[t]{12}{*}{ COB2-1390 } \\
\hline & 0.7966 & 24.4978 & Yangambi_GIL3 & OG-M & 1 & $8 / 05 / 2014$ & \\
\hline & 0.8081 & 24.5281 & Yangambi_GIL4 & OG-M & 1 & $21 / 06 / 2013$ & \\
\hline & 0.7894 & 24.5175 & Yangambi_JEU1 & RF & 1 & $20 / 06 / 2013$ & \\
\hline & 0.7949 & 24.4919 & Yangambi_JEU2 & RF & 1 & $7 / 05 / 2014$ & \\
\hline & 0.7967 & 24.4941 & Yangambi_JEU3 & RF & 1 & $13 / 07 / 2015$ & \\
\hline & 0.7931 & 24.4901 & Yangambi_JEU4 & RF & 1 & $16 / 07 / 2016$ & \\
\hline & 0.7921 & 24.4972 & Yangambi_JEU5 & RF & 1 & $17 / 07 / 2016$ & \\
\hline & 0.8135 & 24.5126 & Yangambi_MIX2 & OG-X & 1 & $16 / 07 / 2016$ & \\
\hline & 0.7805 & 24.5211 & Yangambi_MIX3 & OG-X & 1 & $20 / 06 / 2013$ & \\
\hline & 0.8144 & 24.4931 & Yangambi_MIX5 & OG-X & 1 & $12 / 07 / 2015$ & \\
\hline & 0.8026 & 24.4875 & Yangambi_MIX6 & OG-X & 1 & $7 / 05 / 2014$ & \\
\hline \multirow{2}{*}{$\begin{array}{l}\text { Yelenge } \\
\text { (JCM) }\end{array}$} & 0.6387 & 25.0780 & Yelenge_FP & OG-X & 1 & $6 / 03 / 2005$ & \multirow[t]{2}{*}{ R27622-27981 } \\
\hline & 0.6387 & 25.0780 & Yelenge_FS & RF & 1 & $6 / 03 / 2005$ & \\
\hline \multirow{13}{*}{$\begin{array}{l}\text { Yoko } \\
\text { (JCM) }\end{array}$} & 0.2940 & 25.2881 & Babogombe_FPG_L1 & OG-M & 5 & $21 / 04 / 2007$ & \multirow[t]{13}{*}{ LEGM400-3017 } \\
\hline & 0.2940 & 25.2881 & Babogombe_FPG_L2 & OG-M & 5 & $22 / 02 / 2007$ & \\
\hline & 0.2940 & 25.2881 & Babogombe_FP_L1 & OG-X & 8 & $14 / 12 / 2006$ & \\
\hline & 0.2940 & 25.2881 & Babogombe_FP_L2 & OG-X & 7 & $14 / 12 / 2006$ & \\
\hline & 0.2940 & 25.2881 & Babogombe_FP_L3 & OG-X & 9 & $21 / 04 / 2007$ & \\
\hline & 0.2940 & 25.2881 & Babogombe_FS_L1 & RF & 3 & $14 / 12 / 2006$ & \\
\hline & 0.2940 & 25.2881 & Babogombe_FS_L2 & RF & 3 & $14 / 12 / 2006$ & \\
\hline & 0.2940 & 25.2881 & Babogombe_JJ_L1 & $\mathrm{FL}$ & 3 & $15 / 12 / 2006$ & \\
\hline & 0.2940 & 25.2881 & Babogombe_JV_L1 & $\mathrm{FL}$ & 3 & $23 / 02 / 2007$ & \\
\hline & 0.2940 & 25.2881 & Babogombe_JV_L2 & $\mathrm{FL}$ & 2 & $15 / 12 / 2006$ & \\
\hline & 0.3234 & 25.2539 & Kisesa_JJ & $\mathrm{FL}$ & 8 & $18 / 10 / 2007$ & \\
\hline & 0.3234 & 25.2539 & Kisesa_JV & $\mathrm{FL}$ & 8 & $18 / 10 / 2007$ & \\
\hline & 0.3234 & 25.2539 & Kisesa_VPS & OP & 8 & $18 / 10 / 2007$ & \\
\hline
\end{tabular}

In the study area, forest disturbance is mainly in the form of slash-and-burn agricultural activities, followed by abandonment and secondary succession. Fallow land, the pioneer stage of forest recolonisation, contains dense thickets with few tall trees. Regrowth forests generally are dominated by Musanga cecropioides in the canopy. Old-growth, closed canopy forests represent a range of vegetation, including mixed, semi-deciduous forest, monodominant forest of Gilbertiodendron dewevrei (De Wild.) J. Leonard and 
monodominant forest of Brachystegia laurentii (De Wild.) Hoyle. In some localities, sampling was also conducted in abandoned oil palm plantations. Apart from Yangambi (Van de Perre et al. 2018), quantitative data on tree composition of each sampling site is lacking.

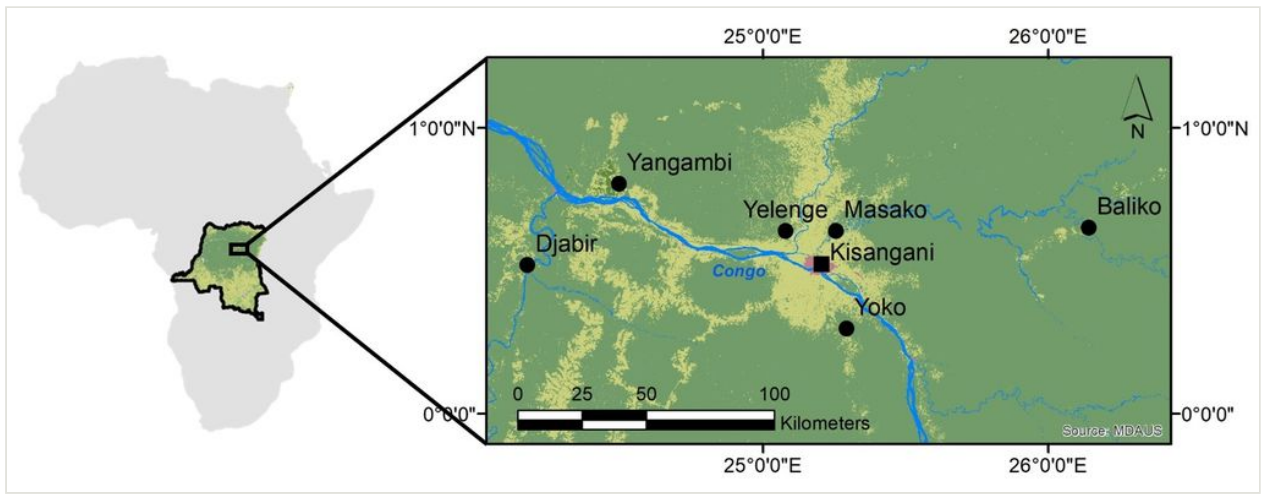

Figure 1. doi

Sampling localities (dots) in the environs of Kisangani (see Table 1 for additional details). The city of Kisangani (square) is surrounded by a mosaic of agricultural land and regrowth forest (light green), while old-growth forests (dark green) can be found throughout the area. Blue lines represent the Congo River and its tributaries. The map on the left shows the situation of the study area within Africa.

Following the revised Köppen-Geiger classification (Peel et al. 2007), the climate of the region is Af-type tropical rainforest climate. At the Yangambi meteorological station, the annual precipitation is $1839.5 \pm 205.7 \mathrm{~mm}$ (1980-2012) and average dry season length is $3.3 \pm 1.3$ months (a month is dry if it receives less than $100 \mathrm{~mm}$ of precipitation). Dry seasons occur in December-February and June-August. Temperatures are high and constant throughout the year, with a minimum of $24.2 \pm 0.4^{\circ} \mathrm{C}$ in July and a maximum of $25.5 \pm 0.6^{\circ} \mathrm{C}$ in March (Doetterl et al. 2015).

Funding: F.V.d.P. was supported by a Ph.D. fellowship from the Research Foundation Flanders and by the Belgian Science Policy Office (COBIMFO Project; Congo Basin integrated monitoring for forest carbon mitigation and biodiversity; contract no. SD/AR/ 01A).

\section{Sampling methods}

Sampling description: In all localities, shrews were sampled using the paceline method, which involved placing 20 pitfall traps at $5 \mathrm{~m}$ intervals on transects (Nicolas et al. 2003). Pitfall traps consisted of non-baited buckets $(10$-litre, $30 \times 30 \times 23 \mathrm{~cm})$ that were buried in the ground, with rims even with the ground surface. A plastic drift fence $(100 \mathrm{~m})$ was set to increase capture effectiveness by guiding shrews toward traps. Pitfall traps were maintained at their locations for 21 days and were checked daily. Only in Yoko, these pitfall 
lines were set for multiple sessions at the same location. In all other locations, trapping was only conducted once (Table 1).

Quality control: Species were identified based on external morphology and cranio-dental characteristics. In addition, species assignments were confirmed for several specimens of each species by molecular analysis (16s rRNA). Taxonomic nomenclature follows Hutterer (2005). Specimens belonging to problematic species complexes that are in need of revision were provisionally labelled with cheironyms, pending formal description.

Step description: Field measurements

Sex and sexual condition were noted for each specimen:

- Males:

- testes: abdominal

- $\quad$ swelling of the epididymis: visible or not

- Females:

vagina: closed or perforated

nipples: small or swollen, lactating

pregnant: yes or no

Following measurements were taken from those specimens that were completely intact:

- Weight (in grams)

- $\quad$ Body length (head - tailbone, in $\mathrm{mm}$ )

- Length of tail (tail length in mm of the point of curvature (anus) until the tip of the tail)

- $\quad$ Size of the left hind leg $(0.1 \mathrm{~mm})$

- $\quad$ Size of the left ear $(0.1 \mathrm{~mm})$

\section{Sample collection}

Samples of liver, spleen and kidney were stored in 96\% alcohol and RNA-later (only kidney). Blood samples were transferred to filter paper. Ectoparasites were preserved in $70 \%$ alcohol. Carcasses of specimens were stored at the Laboratory of Ecology and Animal Resource Management (University of Kisangani) and the Zoologisches Forschungsmuseum Alexander Koenig (Bonn). Tissues samples are stored at the Evolutionary Ecology Lab (University of Antwerp) and at the Royal Belgian Institute of Natural Sciences (Brussels). All specimens are stored under their field number.

For the collection in Yangambi, pictures were taken of each specimen's ventral, dorsal and lateral sides.

\section{DNA Barcoding}

DNA analysis of 16S-rRNA was conducted for a selection of individuals. For PCR amplification, we used the primer pair 16Sar-L (forward: 5'CGCCTGTTTATCAAAAACAT-3', Palumbi et al. 1991) and 16S-Hm (reverse: 
5'AGATCACGTAGGACTTTAAT-3', Quérouil et al. 2001). PCR amplification was performed in 15- $\mu$ l reaction mixtures that contained $7.5 \mu$ Q Qiagen Multiplex, $0.2 \mu \mathrm{M}$ of each primer, $1.5 \mu \mathrm{l}$ DNA template and $5.4 \mu \mathrm{l}$ sterile deionised water. The reaction mixtures were preheated at $95^{\circ} \mathrm{C}$ for $15 \mathrm{~min}$, followed by 42 amplification cycles $\left(95^{\circ} \mathrm{C}\right.$ for $30 \mathrm{~s}, 46^{\circ} \mathrm{C}$ for $90 \mathrm{~s}$ and $72^{\circ} \mathrm{C}$ for $90 \mathrm{~s}$ ), with a final $10 \mathrm{~min}$ extension at $72^{\circ} \mathrm{C}$. The samples were purified and sequenced in both directions at VIB Genetic Service Facility (University of Antwerp). Sequences were aligned using the Geneious software (Drummond et al. 2015).

\section{Geographic coverage}

Description: Lowland forests of the Kisangani, Isangi and Ubundu territories of the Tshopo province (former province Orientale), Democratic Republic of Congo.

Coordinates: $0^{\circ} \mathrm{N}$ and $1^{\circ} \mathrm{N}$ Latitude; $24^{\circ} \mathrm{E}$ and $27^{\circ} \mathrm{E}$ Longitude.

\section{Taxonomic coverage}

Description: All species belong to the family Soricidae, particularly the subfamily Crocidurinae. The dataset contains species from 5 genera: Crocidura (14 species), Paracrocidura (1), Scutisorex (2), Suncus (1) and Sylvisorex (4) (Table 2).

\section{Table 2.}

Number of specimens per species caught in each locality.

\begin{tabular}{|c|c|c|c|c|c|c|}
\hline Species & Djabir & Yoko & Yangambi & Yelenge & Masako & Baliko \\
\hline Crocidura caliginea Hollister, 1916. & - & - & 52 & 3 & 14 & 7 \\
\hline $\begin{array}{l}\text { Crocidura crenata Brosset, Dubost \& Heim de Balsac, } \\
1965 .\end{array}$ & - & - & 9 & 5 & 2 & 0 \\
\hline Crocidura denti Dollman, 1915. & - & - & 104 & 8 & 25 & 11 \\
\hline Crocidura dolichura Peters, 1876. & 13 & 111 & 8 & 6 & 5 & 0 \\
\hline Crocidura cf. fuscomurina Heuglin, 1865 & - & 4 & - & - & - & - \\
\hline Crocidura goliath Thomas, 1906. & 0 & 10 & - & - & - & - \\
\hline $\begin{array}{l}\text { Crocidura grassei Brosset, Dubost \& Heim de Balsac, } \\
1965 .\end{array}$ & 0 & 26 & - & - & - & - \\
\hline Crocidura latona Hollister, 1916. & 21 & 168 & 0 & 1 & 26 & 0 \\
\hline Crocidura littoralis Heller, 1910. & 27 & 24 & 153 & 44 & 21 & 4 \\
\hline Crocidura ludia Hollister, 1916. & 4 & 1013 & 27 & 0 & 34 & 11 \\
\hline Crocidura cf. maurisca Thomas, 1904 & 0 & 1 & - & - & - & - \\
\hline Crocidura cf. muricauda Miller, 1900 & - & - & 4 & 0 & 1 & 0 \\
\hline Crocidura olivieri Lesson, 1827. & 6 & 173 & 43 & 0 & 11 & 10 \\
\hline
\end{tabular}




\begin{tabular}{|c|c|c|c|c|c|c|}
\hline Species & Djabir & Yoko & Yangambi & Yelenge & Masako & Baliko \\
\hline Crocidura yoko sp1 & 0 & 64 & - & - & - & - \\
\hline Paracrocidura schoutedeni Heim de Balsac, 1956. & 3 & 47 & 6 & 6 & 33 & 4 \\
\hline Scutisorex congicus Thomas, 1915. & - & - & 4 & 1 & 22 & 6 \\
\hline Scutisorex n.sp. & - & 75 & - & - & - & - \\
\hline Suncus cf. remyi Brosset, Dubost \& Heim de Balsac, 1965. & - & - & 27 & 0 & 5 & 5 \\
\hline Sylvisorex akaibei Mukinzi, Hutterer \& Barriere, 2009. & - & - & 27 & 1 & 0 & 1 \\
\hline Sylvisorex cf. johnstoni Dobson, 1888. & - & - & 12 & 5 & 16 & 14 \\
\hline Sylvisorex nsp1 & 0 & 11 & - & - & - & - \\
\hline Sylvisorex cf. ollula Thomas, 1913. & 6 & 275 & - & - & - & - \\
\hline Unidentified specimens & 14 & 15 & 9 & 26 & 8 & 3 \\
\hline Total & 94 & 2017 & 485 & 106 & 223 & 76 \\
\hline
\end{tabular}

The dataset contains a number of specimens that likely belong to species new to science. Specimens morphologically resembling known species but found far outside the distribution of the known species have been identified using a cf. statement, others were named using a cheironym.

Crocidura sp1 yoko has easily distinguishable characteristics: small size (4-6 g), brownish on the back, greyish-brown on the belly, brownish tail that is completely glabrous, except from the base which is covered with few small vibrissae, the down side of the tail clear, almost white at the base and around the anus and its small paws are equally light coloured (Fig. 2). Its skull resembles that of Crocidura Iudia but is smaller (Mukinzi-Itoka 2014).

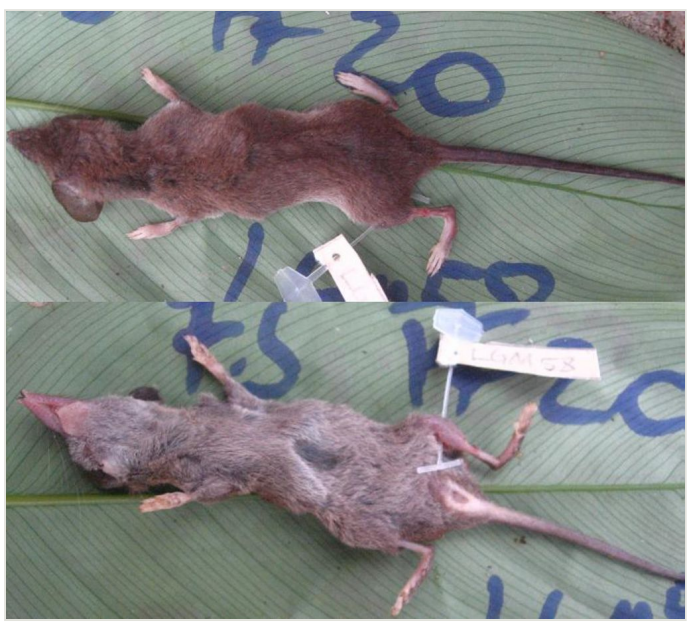

Figure 2. doi

Dorsal and ventral view of Crocidura sp1 yoko (LEGM458, Mukinzi 2014). 
Sylvisorex n.sp. is a small and rare species. Brown greyish on the back and silvery grey on the belly. It has a long tail covered with small hairs that grow longer and are more numerous towards the tip, forming a white brush. The tail is brown-black on top and slightly lighter on the bottom (Fig. 3). The species resembles Crocidura polia Hollister, 1916. However, the new species has little vibrissae on its tail while, in C. polia, half of the tail is covered with vibrissae (Mukinzi 2014).

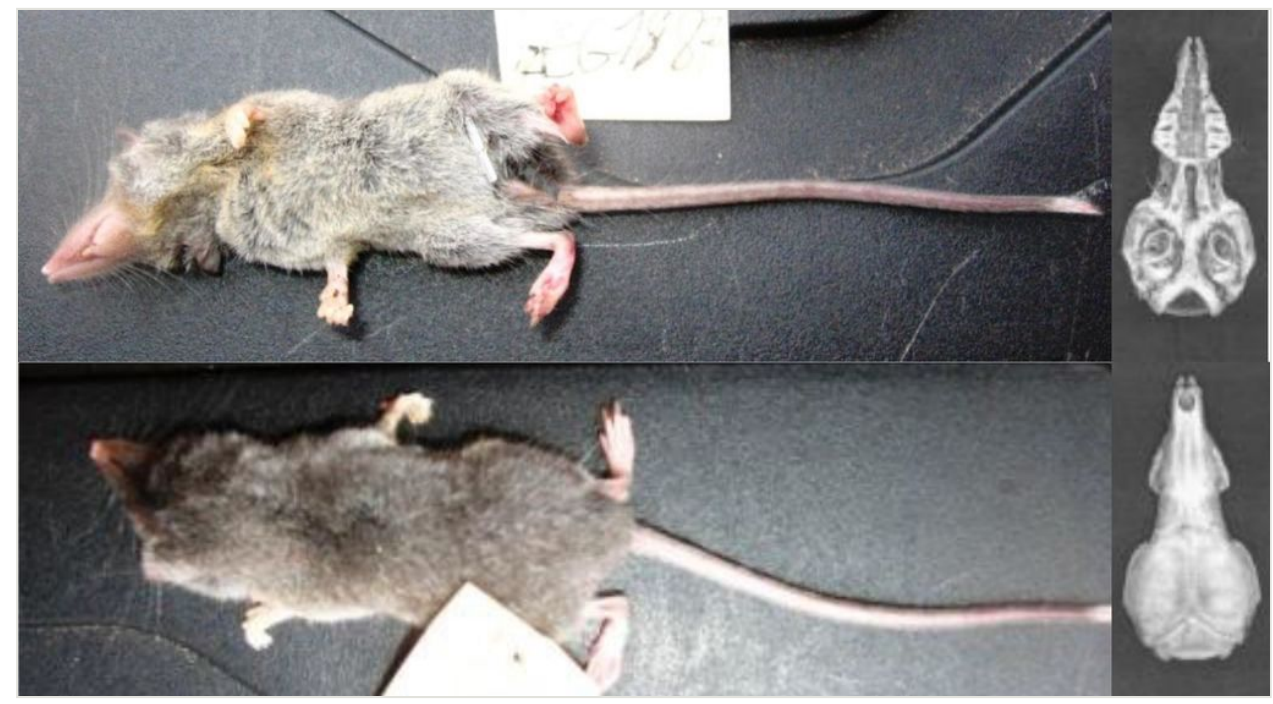

Figure 3. doi

Dorsal and ventral view of body and skull of Sylvisorex n. sp. (LEGM1887, Mukinzi 2014).

Scutisorex n. sp. (description in progress, J. Hulselmans pers. comm.) was found in RF Yoko and its distribution seems to be limited to the forest bloc between the Lomami and Lualaba.

\section{Temporal coverage}

Notes: 8 June 2005 (Yelenge) to 7 August 2014 (Yangambi).

\section{Collection data}

Collection name: Carcasses of specimens were stored at the Laboratory of Ecology and Animal Resource Management, University of Kisangani. Tissues samples are stored the University of Antwerp and at the Royal Belgian Institute of Natural Sciences. For the collection of Yangambi, pictures were taken of each specimen's ventral, dorsal and lateral sides.

Specimen preservation method: Samples of liver, spleen and kidney were stored in $96 \%$ alcohol and RNA-later (only kidney). Blood samples were transferred to filter paper. 
Ectoparasites were preserved in $70 \%$ alcohol. Specimen carcasses were stored in $70 \%$ alcohol.

\section{Usage rights}

Use license: Creative Commons Public Domain Waiver (CC-Zero)

\section{Data resources}

Data package title: African Mammalia

Resource link: http://projects.biodiversity.be/africanmammalia

\section{Number of data sets: 3}

Data set name: Specimen list

Download URL: http://projects.biodiversity.be/africanmammalia/search

Data format: .csv

Description: The data can be downloaded from the online database, African Mammalia. Shrew specimens can be searched through the 'Search' or 'Taxa' tab.

\begin{tabular}{|c|c|}
\hline Column label & Column description \\
\hline Collection number & Museum collection number \\
\hline Order & Taxonomic rank \\
\hline Family & Taxonomic rank \\
\hline Family author & Author(s) and publication date of family \\
\hline Genus & Taxonomic rank \\
\hline Genus author & Author(s) and publication date of genus \\
\hline Species & Taxonomic rank \\
\hline Species author & Author(s) and publication date of species \\
\hline Subspecies & Taxonomic rank \\
\hline Subspecies author & Author(s) and publication date of subspecies \\
\hline Determinator & Determinator of specimen \\
\hline Determination year & Determination year \\
\hline Accuracy & Accuracy of determination \\
\hline Field number & Unique identifier of specimen \\
\hline Locality & Sampling locality \\
\hline
\end{tabular}




\begin{tabular}{|c|c|}
\hline Altitude & Altitude of sampling location in metres \\
\hline Altitude max & Maximum altitude \\
\hline Country iso code & CD \\
\hline Country & Democratic Republic Congo \\
\hline Latitude & Latitude of sampling locality in decimal degrees \\
\hline Longitude & Longitude of sampling locality in decimal degrees \\
\hline Collector & Collector of specimen \\
\hline Date collected & Date of collection \\
\hline Date collected end & End of data collection \\
\hline Sex & $m$, Male - $f$, Female \\
\hline Sexual condition name & Sexual condition, see above \\
\hline Sexual condition code & Sexual condition code \\
\hline Age & Age of specimen \\
\hline Weight & Weight in gram \\
\hline Type & Holotype, paratype or syntype \\
\hline Trap & Type of trap used \\
\hline Available & Whether the specimen is present in the collection \\
\hline Basis of record & Preserved specimen or observation \\
\hline Tissues & Whether tissue samples are available \\
\hline url & Link to the specimen information on African Mammalia \\
\hline
\end{tabular}

Data set name: Sequences

Download URL: http://projects.biodiversity.be/africanmammalia/search

Data format: .csv

Description: Export of DNA sequences and metadata.

\begin{tabular}{|l|l|}
\hline Column label & Column description \\
\hline Collection number & Museum collection number \\
\hline Field number & Field number \\
\hline Basis of record & Preserved specimen or observation \\
\hline Family & Family, Soricidae \\
\hline Genus & Genus name \\
\hline
\end{tabular}




\begin{tabular}{|l|l|}
\hline Species & Species name \\
\hline Subspecies & Subspecies name \\
\hline Accession number & Genbank accession number \\
\hline Sequence number & Unique sequence code \\
\hline Sequence & DNA sequence \\
\hline url & Link to the specimen information on African Mammalia. \\
\hline
\end{tabular}

Data set name: Measurements

Download URL: http://projects.biodiversity.be/africanmammalia/search

Data format: .csv

Description: Export of morphological measurements and metadata.

\begin{tabular}{|c|c|}
\hline Column label & Column description \\
\hline $\begin{array}{l}\text { Collection } \\
\text { number }\end{array}$ & Museum collection number \\
\hline Field number & Unique field code \\
\hline Basis of record & Preserved specimen or observation \\
\hline Familiy & Family, Soricidae \\
\hline Genus & Genus name \\
\hline Species & Species name \\
\hline Subspecies & Subspecies name \\
\hline Sex & Sex (Male or Female) \\
\hline $\mathrm{hb}$ & Head-body length \\
\hline tl & Tail length \\
\hline hf & Hind foot length \\
\hline el & Ear length \\
\hline m1-m25 & $\begin{array}{l}\text { Craniometric measurement, description available on http://projects.biodiversity.be/ } \\
\text { africanmammalia/about/data\#measurements }\end{array}$ \\
\hline url & Link to the specimen information on African Mammalia. \\
\hline
\end{tabular}




\section{Additional information}

\section{Results communication:}

Results of diversity analyses have already been published in peer-reviewed journals (in chronological order):

- $\quad$ Mukinzi et al. (2005)

- Gambalemoke et al. (2008a)

- Gambalemoke et al. (2008b)

- Mukinzi et al. (2009)

- $\quad$ Van de Perre et al. (2018)

\section{Acknowledgements}

Fieldwork was carried out in collaboration with the Centre de Surveillance de la Biodiversité at the University of Kisangani. We thank Y. Mutafchiev, R. Mesibov, R. Hutterer, V. Nicolas, S. Solari, A. Balakirev and an anonymous reviewer for helpful comments on earlier versions of this manuscript.

\section{Author contributions}

Jean-Claude Mukinzi Itoka, Sylvestre Gambalemoke Mbalitini and Frederik Van de Perre are the main collectors of specimens and observations. Frederik Van de Perre sequenced the specimens. Julien Cigar developed the online database. Frederik Van de Perre wrote the first version of the manuscript and all co-authors contributed to the writing.

\section{References}

- $\quad$ Alroy J (2017) Effects of habitat disturbance on tropical forest biodiversity. Proceedings of the National Academy of Sciences 114 (23): 6056-6061. https://doi.org/10.1073/pnas. 1611855114

- $\quad$ Churchfield S, Barrière P, Hutterer R, Colyn M (2004) First results on the feeding ecology of sympatric shrews (Insectivora: Soricidae) in the Tai National Park, Ivory Coast. Acta Theriologica 49 (1): 1-15. https://doi.org/10.1007/bf03192504

- Colyn M, Hulselmans J, Sonet G, Oudé P, De Winter J, Natta A, Nagy ZT, Verheyen E (2010) Discovery of a new duiker species (Bovidae: Cephalophinae) from the Dahomey Gap, West Africa. Zootaxa 2637 (1): 1-30. https://doi.org/10.11646/zootaxa.2637.1.1

- Doetterl S, Kearsley E, Bauters M, Hufkens K, Lisingo J, Baert G, Verbeeck H, Boeckx $P$ (2015) Aboveground vs. belowground carbon stocks in African tropical lowland rainforest: Drivers and implications. PloS One 10 (11): e0143209. https://doi.org/ 10.1371/journal.pone.0143209 
- Drummond AJ, Ashton B, Buxton S, Chueng M, Cooper A, Heled J, Kearse M, Moir R, Stones-Havas S, Sturrock S, Thierer T, Wilson A (2015) Geneious. 7.1.9. Release date: 2015-5-22. URL: http://www.geneious.com

- Gambalemoke M, Mukinzi I, Amundala D, Katuala G, Kennis J, Dudu A, Hutterer R, Barrière $P$, Leirs $H$, Verheyen $E$ (2008a) Shrew trap efficiency: experience from primary forest, secondary forest, old fallow land and old palm plantation in the Congo River basin (Kisangani, Democratic Republic of Congo). Mammalia 72 (3): 203-212. https:// doi.org/10.1515/mamm.2008.039

- Gambalemoke M, Mukinzi I, Amundala D, Gembu T, Kaswera K, Katuala G, Dudu A, Barrière P, Colyn M, Hutterer R, Kennis J, Leirs H, Vanlinden B, Verheyen E (2008b) Microgeographical distribution of shrews (Mammalia, Soricidae) in the Congo River basin (Kisangani, D.R. Congo). Mammalia 72 (3): 213-222. https://doi.org/10.1515/ MAMM.2008.043

- $\quad$ Gambalemoke M (2014) Phylogeographie et biodiversité des musaraignes (Soricomorpha, Crocidurinae) en cuvette congolaise. University of Kisangani, Kisangani, DRC, $214 \mathrm{pp}$.

- Gibson L, Lee TM, Koh LP, Brook B, Gardner T, Barlow J, Peres C, Bradshaw CA, Laurance W, Lovejoy T, Sodhi N (2011) Primary forests are irreplaceable for sustaining tropical biodiversity. Nature 478 (7369): 378-381. https://doi.org/10.1038/nature10425

- Hutterer R (2005) Order Soricomorpha . In: Wilson DE, Reeder DA (Eds) Mammal species of the World: a taxonomic and geographic reference. Third edition. Johns Hopkins University Press, Baltimore, 220-311 pp.

- Jacquet F, Denys C, Verheyen E, Bryja J, Hutterer R, Kerbis Peterhans JC, Stanley WT, Goodman SM, Couloux A, Colyn M, Nicolas V (2015) Phylogeography and evolutionary history of the Crocidura olivieri complex (Mammalia, Soricomorpha): from a forest origin to broad ecological expansion across Africa. BMC Evolutionary Biology 15 (1): 71.

https://doi.org/10.1186/s12862-015-0344-y

- $\quad$ Lewis SL (2005) Tropical forests and the changing earth system. Philosophical Transactions of the Royal Society B: Biological Sciences 361 (1465): 195-210. https:// doi.org/10.1098/rstb.2005.1711

- Malhi Y, Adu-Bredu S, Asare RA, Lewis SL, Mayaux P (2013) African rainforests: past, present and future. Philosophical Transactions of the Royal Society B: Biological Sciences 368 (1625): 20120312. https://doi.org/10.1098/rstb.2012.0312

- Mittermeier RA, Mittermeier CG, Brooks TM, Pilgrim JD, Konstant WR, da Fonseca GAB, Kormos C (2003) Wilderness and biodiversity conservation. Proceedings of the National Academy of Sciences 100 (18): 10309-10313. https://doi.org/10.1073/pnas. 1732458100

- Mukinzi I, Katuala PG, Kennis J, Gambalemoke M, Kadange N, Dudu AM, Colyn M, Hutterer R (2005) Preliminary data on the biodiversity of rodents and insectivores (Mammalia) in the periphery of Kisangani (DR Congo). Belgian Journal of Zoology 135: 133-140.

- $\quad$ Mukinzi I, Hutterer R, Barrière P (2009) A new species of Sylvisorex (Mammalia: Soricidae) from lowland forests north of Kisangani, Democratic Republic of Congo. Mammalia 73: 130-134. https://doi.org/10.1515/MAMM.2009.031

- Mukinzi I (2014) Biodiversité et ecologie des musaraignes (Soricomorpha, Mammalia) de la Reserve Forestière de Yoko et des milieux perturbés environnants (Ubundu, R.D. Congo). University of Kisangani 
- $\quad$ Nicolas V, Barrière P, Colyn M (2003) Impact of removal pitfall trapping on the community of shrews (Mammalia: Soricidae) in two African tropical forest sites. Mammalia 67: 133-138. https://doi.org/10.1515/mamm.2003.67.1.133

- Palumbi S, Martin A, Romano S, McMillan WO, Stice L, Grabowski G (1991) The simple fool's guide to PCR, version 2.0. Univ. of Hawaii.

- $\quad$ Peel MC, Finlayson BL, McMahon TA (2007) Updated world map of the Köppen-Geiger climate classification. Hydrology and Earth System Sciences 11 (5): 1633-1644. https:// doi.org/10.5194/hess-11-1633-2007

- $\quad$ Phillips HP, Newbold T, Purvis A (2017) Land-use effects on local biodiversity in tropical forests vary between continents. Biodiversity and Conservation 26 (9): 2251-2270. https://doi.org/10.1007/s10531-017-1356-2

- Quérouil S, Hutterer R, Barrière P, Colyn M, Kerbis Peterhans J, Verheyen E (2001) Phylogeny and evolution of African shrews (Mammalia: Soricidae) inferred from 16s rRNA sequences. Molecular Phylogenetics and Evolution 20 (2): 185-195. https:// doi.org/10.1006/mpev.2001.0974

- Quérouil S, Verheyen E, Dillen M, Colyn M (2003) Patterns of diversification in two African forest shrews: Sylvisorex johnstoni and Sylvisorex ollula (Soricidae, Insectivora) in relation to paleo-environmental changes. Molecular Phylogenetics and Evolution 28 (1): 24-37. https://doi.org/10.1016/s1055-7903(03)00027-7

- Stanley WT, Robbins LW, Malekani JM, Mbalitini SG, Migurimu DA, Mukinzi JC, Hulselmans J, Prevot V, Verheyen E, Hutterer R, Doty JB, Monroe BP, Nakazawa YJ, Braden Z, Carroll D, Kerbis Peterhans JC, Bates JM, Esselstyn JA (2013) A new hero emerges: another exceptional mammalian spine and its potential adaptive significance. Biology Letters 9 (5): 20130486. https://doi.org/10.1098/rsbl.2013.0486

- Van de Perre F, Willig M, Presley S, Andemwana FB, Beeckman H, Boeckx P, Cooleman S, de Haan M, De Kesel A, Dessein S, Grootaert P, Huygens D, Janssens S, Kearsley E, Kabeya PM, Leponce M, Van den Broeck D, Verbeeck H, Würsten B, Leirs $H$, Verheyen $E$ (2018) Reconciling biodiversity and carbon stock conservation in an Afrotropical forest landscape. Science Advances 4 (3): eaar6603. https://doi.org/ 10.1126/sciadv.aar6603

- Van de Perre F, Leirs H, Verheyen E (2019) Paleoclimate, area size, and degree of isolation explain regional biodiversity differences among terrestrial vertebrates within the Congo basin. Belgian Journal of Zoology 149 (1): 23-42. https://doi.org/10.26496/ bjz.2019.28 